\title{
An Econometric Analysis Of Bank Lending And Agricultural Output In South Africa: A Survey Approach
}

Joseph Chisasa, University of South Africa, South Africa

\begin{abstract}
This paper analyses the role of credit on the performance of smallholder farmers in South Africa. Applying survey data involving 362 respondents from North West and Mpumalanga provinces the study utilises the Ordinary Least Squares to estimate the Cobb-Douglas production function with agricultural output as the endogenous variable and bank credit, land, labour and rainfall as the independent variables. Credit is observed to have a positive and significant influence on the agricultural output of smallholder farmers at the 1\% level of significance. A $1 \%$ increase in the amount of credit yields a combined incremental effect of $0.375 \%$ on output. When disaggregated, short-term credit contributes $0.14 \%$ while long-term credit induces output growth of $0.231 \%$. The coefficient for land was found to be positive and significant at 5\%. Labour and rainfall, albeit positive were insignificant. The paper concludes that availability of both bank credit and land stimulate growth in the agricultural sector. Therefore policies directed at increasing the supply of credit to smallholder farmers are recommended.
\end{abstract}

Keywords: Bank Lending; Smallholder Farmer; Agricultural Output; South Africa

\section{INTRODUCTION}

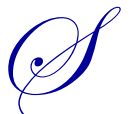

outh Africa is characterised by a dualistic agricultural sector consisting of a vibrant commercial and a smallholder farming sector. Smallholder farmers have encountered a myriad of challenges such as lack of inputs and capital equipment to transform themselves from mere household production enterprises to fully-fledged commercial enterprises. At a macroeconomic level, the agricultural sector contributes about $3 \%$ to Gross Domestic Product (GDP). When compared to other sectors, its contribution is observed to be minute. Yet with a growing population of 52 million and estimated to reach 95 million by 2050, South Africa needs to focus on strengthening food production and food security. Although the country is currently food secure the need for hedging against the risk of hunger and starvation is apparent. The agricultural sector is of strategic importance to South Africa because it employs the highest number of people both on the farms and in agro-industries. Smallholder farmers provide an opportunity for employment creation and growth potential.

Since attaining freedom from Apartheid rule in 1994, the smallholder farming sector in South Africa has grown in lips and bounds. Empirical evidence has attributed the slow growth to market failures such as lack of access to credit and markets for the produce. In South Africa, smallholder farmers are believed to hold the solution to problems such as unemployment to a growing population of 52 million people. Furthermore the majority of South Africans lives in rural areas and depends mainly on agriculture for their livelihood. As such, over the years government has fostered the growth of credit supply to smallholder farmers without much success. Chisasa and Makina (2012) demonstrated that credit to smallholder farmers lagged that to commercial farmers and private sector in a trend analysis of credit supply spanning the period 1970 to 2009.

Empirical evidence suggests that smallholder farmers in South Africa have performed badly due to lack of access to formal sources of credit (Coetzee et al., 2002; Lahiff and Cousins, 2005) demonstrating that smallholder farmers are credit constrained. Chisasa and Makina (2013) extended these studies using secondary time series data 
for the period 1970 to 2009 and showed that at a macroeconomic level, credit has a positive and significant influence on agricultural output. While these studies concur that smallholder farmers are credit constrained, none of them addressed the relationship between bank credit and the performance of smallholder farmers which are largely credit constrained when compared to large-scale commercial farmers (Chisasa and Makina, 2012). This is the focus of this paper.

The rest of the paper proceeds as follows. Section presents the literature review. Section 3 discusses the methodology. The results are presented in section 4 while section 5 concludes.

\section{LITERATURE REVIEW}

The variables that enter the agricultural production function have been documented substantially in the literature (Sial et al., 2011; Enoma, 2010). These studies have applied the Cobb-Douglas (1928) production function to establish the relationship between credit and agricultural output. In general, there is consensus that credit influences agricultural output and its coefficient is positive. The other variables included in the agricultural production function are land, rainfall and capital.

The use of credit as an independent variable in the agricultural production function in empirical studies has been challenged (see for example Driscoll (2004:469) and Nkurunziza (2010:489). However, Sial et al (2011:128) have argued that improved seeds and other inputs like tractors, fertilizer and biocides that may be purchased using credit money play an important role in agricultural production and these can be directly influenced by the availability of credit.

The inclusion of credit as an explanatory variable in the production function is usually challenged on the grounds that it does not affect the output directly; rather it has an indirect effect on output through easing the financial constraints of the producers in purchasing inputs (Carter, 1989). Carter (1989) argues that credit affects production in the agricultural sector in three ways: (i) it encourages efficient resources allocation by overcoming constraints to purchase inputs and use them optimally - "...this sort of effect would shift the farmer along a given production surface to a more intensive and more remunerative input combination"; (ii) if the credit is used to buy a new package of technology, say high-yielding seed and other unaffordable expensive inputs, it would help farmers to move not only closer to the production frontier but also shift the entire input-output surface - in this regard it embodies technological change and a tendency to increase technical efficiency of the farmers, and (iii) credit can also increase the use intensity of fixed inputs like land (Kumar et al.,2010:15), family labour, and management, persuaded by the 'nutrition-productivity link of credit' - that raises family consumption and productivity. Carter's reasoning implies that agricultural credit not only improves management efficiency but also affects the resource allocation and profitability.

Gosa and Feher (2010) analysed the financial resource implications on agriculture performance in Romania taking into account both bank and trade credit. First, direct bank credit to agriculture was observed to be low paving way for the development of trade credit (supplier's credit). Trade credit is a financing alternative agreed, in case of need, by input beneficiaries (farmers) and suppliers as well. Second, although trade credit was found to be more expensive than bank credit, it was seen to be more operative and thus more appealing. It can be inferred from this analysis that not only is credit required to enhance farmer profitability as was later concluded by Gosa and Feher (2010:7), but that the turnaround time for accessing the credit was also found to be key.

Obilor (2013:91) hypothesised first, that commercial bank credit has not significantly influenced productivity in Nigeria. In the second hypothesis, it was postulated that agricultural credit guarantee scheme loan by purpose has not led to significant growth in productivity in Nigeria. Using t-tests, the high probability of the critical value demonstrated a significant null hypothesis. Thus the null hypothesis was accepted at $5 \%$ level of significance leading to conclusions that commercial banks' credit to agricultural sector for the period 1984 to 2007 had no significant positive impact on productivity in Nigeria. However, the second null hypothesis was rejected and it was concluded that the agricultural credit guarantee scheme loan by purpose led to a significant positive growth in agricultural productivity in Nigeria. Thus, while generally concurring that credit is a necessary factor in the agricultural production function, Obilor (2013) emphasises the provision of credit guarantees by government to 
lenders. The credit guarantee scheme indirectly acts as security for the repayment of bank loans advanced to the agricultural sector where loan repayment may be jeopardised by the risky nature of agricultural production. These results confirmed an earlier study by Ammani (2012) in Nigeria.

The strategic role of financial credit in accelerating agricultural production in Nigeria was also analysed by Sogo-Temi and Olubiyo (2004). Generally, it was proved that one of the most important determinants of growth in agricultural output is availability of productive credit. However, it was opined that the insignificance of the parameter estimates could be attributed to diversion of bank credit to non-productive ventures such as marriage, funeral ceremonies and other social functions. Despite this setback, several empirical studies concur that credit is an important instrument that enables farmers to acquire commands over the use of working capital, fixed capital and consumption goods (Sial et al., 2011:7; Simsir, 2012:362). As agriculture is a multi-product industry, Saleem and Jan (2011:3) used Agricultural Gross Domestic Product (AGDP) as the dependent variable and agricultural production was assumed to be the function of credit disbursed by different financial institutions for irrigation purposes, seeds, fertilisers, pesticides, implementation of tractors and other purposes. Over eighty percent of agricultural gross domestic product was observed to be attributable to total credit supplied.

While supporting the hypothesis that institutional credit positively impacts productivity in agriculture in India, Sidhu et al. (2008:407) argue against the uniform supply of credit across all regions. Rather, they suggest that region-specific credit demand patterns must be assessed first, depending on crop patterns and current inputs and capital requirements in relation to targeted output growth rate. Afterwards, a policy framework should be put in place to meet those requirements, instead of increasing the credit supply uniformly across the regions of the country. Subsequently, Kumar et al. (2010:259) reported that regional disparities in the distribution of institutional credit in India seem to have declined over time from 122 percent in 2000-01 to 81 percent in 2007-08. However, 81 percent still remains a significant level which demonstrates that the regional disparities in institutional credit flow do exist and still characterise the rural credit system.

Erratic rainfall is an inherent characteristic of semi-arid sub-humid tropical agro-ecosystems, limiting landscape productivity (Barron et al., 2010:543). Farmers not only have to contend with market risks but also with environmental factors such as weather (Development Bank of Southern Africa, 2011). During drought periods, crops wither before maturity. In times of excess rains, which normally result in floods and water logging, the yields are poor. According to Rouault and Richard (2003:489) the 8 most severe droughts in the history of South Africa since 1921 occurred in 1926, 1933, 1945, 1949, 1952, 1970, 1982 and 1983. See also Blignaut et al (2009:61). The total number of wet and dry districts per decade seems to have increased since the 1960s. Faures et al. (2010:529) argue that harvested area may depend on direct weather factors, for instance, when drought wipes out the crops from a farm, resulting in the harvested area being smaller than the planted area. On the other hand yield is very much the result of the overall health of the plants, which is affected in more or less subtle and direct ways by weather, starting with sunshine, the driver of photosynthesis, and water availability from rainfall and irrigation, which defines to which extent plants can actually make use of available solar energy. In most places, water availability is the factor that most directly conditions crop yields, and in the areas where water is plenty, the main limiting factor usually becomes sunshine. Consequently, rainfall can either have a positive or negative impact on farm output. For instance, droughts and too much rain could have a negative impact while moderate rain could have a positive impact.

South Africa is characterised by a semi-arid climate. To supplement its water requirements for agricultural use, irrigation schemes have been set up. Fanadzo et al (2010:3516) outlined the history of irrigation schemes in South Africa focusing on smallholder irrigation schemes (SIS).

Land is one of the key factors of production across sectors including agriculture (Jaffe and Zeller, 2010:531). Historically, black farming in South Africa has not been supported, while white farming has been given preferential support through government subsidies and legislation. This created a highly dualistic agricultural sector, with black farmers cultivating small pieces of land (Rother et al., 2008:399; Palmer and Sender, 2006:349) with insufficient investment or institutional support (Oettle, 1998:6). Complementary to farmer efforts, government needs to formulate policy that makes it possible for farmers to acquire land to cultivate. As a result, land reform has been a topical subject around the world (Deininger, 2007:16). According to Udoh (2011:290), restrictive laws pertaining to land use need to be amended to make more land available for large scale agriculture. For example, the historical 
imbalances in South Africa require an intervention which will see the transfer of some amount of land to the previously disadvantaged farmers who operate on very small farms.

Progress has been made in addressing the land problem in South Africa. However, one of the constraints to maximising productivity is the farm size. According to MacLeod et al. (2008:76), many of these farmers will not be viable due to limited farm size.

Labour is an integral variable in the agricultural production function. Various definitions of labour have been put forward. For example, Baumol and Blinder (2006:486) define labour input in the production function as the number of hours worked. Holding other factors constant, output rises as labour inputs increase.

Zuberi (1989:53) recommended that any strategy designed to increase agricultural productivity in Pakistan must focus on channelling investment towards human capital development with emphasis being placed on both primary and secondary schools. In the case of South Africa, Fatoki and Odeyemi (2010:133) suggest that educational institutions should introduce and strengthen entrepreneurial education. They argue that when learners are oriented into entrepreneurship at an early age, it increases their probability of success as entrepreneurs. A digression from this view is offered by Dhebhi and Luchaal (2006:255) for Tunisia. After investigating the patterns of productivity in Tunisian agriculture, they observed that capital was the most important contributor to output growth. The variable capital stock was defined as including machinery, installations and buildings. Labour was in fact found to be the least contributor to economic growth. Among other empirical work, these studies attempt to provide answers to the question posed by Cobb and Douglas (1928:140) whether "... it may be possible to determine, again within limits, the relative influence upon production of labour as compared with capital?"

In light of the foregoing, Bratka and Praulins (2009:14) posit that farm profitability is dependent upon both the amount of the factors of production employed and the ability to mix these factors such that profitability is maximised. The ability to productively combine the factors of production is also crucial. As a result of this analysis, Bratka and Praulins hypothesise that some managers are more successful in maximising profits than others. In Cameroon, Bayemi et al. (2009:907) found evidence supporting this hypothesis. A study was conducted to evaluate the impact of management interventions to solve constraints in smallholder dairy farms of the Western Highlands of Cameroon. A reduction in expenditure and an overall increase in farm income were observed. The intervention had a positive impact which led to poverty alleviation and some farmers acquired more cows.

\section{DATA AND METHODOLOGY}

A total of 500 smallholder farmers were surveyed using the multi-stage sampling technique from which 362 responses were received (72.4\%). The questionnaire used for this study was subjected to reliability and validity tests using Cronbach alpha. The instrument was found to be reliable and valid with an alpha value of 0.6. The Cronbach alpha value is an important measure of the reliability of the questionnaire. Its value generally increases when the correlations between the questions of the questionnaire increase. The alpha value can lie between negative infinity and $1(-\infty<\alpha<1)$. Three decision criteria guide the interpretation of Cronbach alpha as follows:

For a value above 0.8 , reliability is considered as good.

For a value between 0.6 and 0.8 , reliability is considered as acceptable.

For a value below 0.6 , reliability is considered unacceptable.

The objective of this study was to empirically determine the impact of bank credit on agricultural output in South Africa. Following on this objective, the following hypothesis was postulated:

$H_{0}$ : There is no supported relationship between bank credit and agricultural output $(\mathrm{b}=0)$.

$H_{a}: b \neq 0$. 


\subsection{Econometric Model Specification}

From the above hypothesis, the following agricultural production function was estimated and the model specified below.

$$
\begin{aligned}
& \text { AgricOutput }(\mathrm{AO})=\mathrm{f}(\operatorname{credit}(\mathrm{C}) ; \text { labour }(\mathrm{L}) ; \text { rainfall }(\mathrm{R}) ; \text { land }(\mathrm{Ld})) \\
& \mathrm{AO}=\beta_{0}+\beta_{1} \mathrm{C}+\beta_{2} \mathrm{~L}+\beta_{3} \mathrm{R}+\beta_{4} \mathrm{Ld}+\varepsilon_{\mathrm{t}}
\end{aligned}
$$

$\beta_{0}-\beta_{4}=$ coefficients

$\varepsilon_{\mathrm{t}}=$ Error term

The specified model was analysed using the Least Squares Method. Results of the analysis are presented below.

\section{RESULTS AND DISCUSSION OF EMPIRICAL RESULTS}

\subsection{Demographic Characteristics Of Respondents}

The study first analysed the demographic characteristics of the respondents. Respondents were asked to indicate their age. The purpose was to determine the age concentration and establish the patterns of interest in farming as a business. Figure 1 below shows that the majority of the respondents were observed to be between 31 and 50 years old $(71.5 \% ; n=362)$ while only $0.3 \%(n=362)$ was over 50 years old. This shows that the bulk of the respondents are still in their active and productive age group. It is also encouraging to note that some of the respondent farmers $(16 \%, \mathrm{n}=362)$ are younger than 30 years of age.

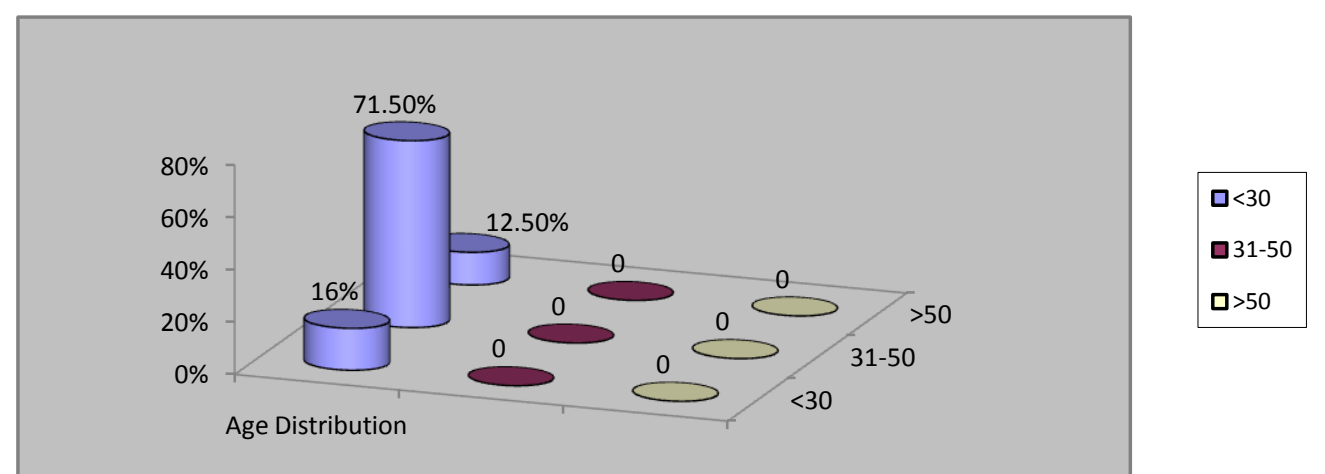

Figure 1: Age Distribution Of Farmers

The majority of farmers are married (48.6\%; $\mathrm{n}=362)$. This suggests that farming is taken seriously for the purpose of generating income for taking care of the family. What is worrying though is that while $39.6 \%(\mathrm{n}=362)$ received high school education, only $4.7 \%(\mathrm{n}=362)$ had received tertiary education. The majority either did not go to school $(14.7 \%$; $n=362)$ or had received primary school education $(37.4 \% ; n=362)$. As anticipated, $65.3 \%(n=362)$ of the respondents were male.

Most of the farmers $(72.2 \% ; \mathrm{n}=362)$ operate on relatively small pieces of land of up to 20 hectares suggesting that farm size could be a constraint in their quest to grow. The respondents were asked to indicate the factors that limit them from borrowing from banks. Distance from the bank and high interest rates were cited as the major impediments to borrowing. On the other hand farmers indicated the need for inputs such as fertiliser, seed and pesticides, payment of wages for workers and irrigation equipment as key drivers for credit demand. 


\subsection{Descriptive Statistics}

Table 1: Descriptive Statistics

\begin{tabular}{lccc}
\hline & Mean & Standard Deviation & N \\
\hline Agricultural output (AO) & 1.59 & 1.034 & 362 \\
Land & 3.22 & 1.417 & 362 \\
Labour & 2.7 & 1.139 & 362 \\
Short-term credit & 1.76 & 1.275 & 362 \\
Long-term credit & 1.65 & 1.279 & 362 \\
Rainfall & 504.36 & 129.383 & 362 \\
\hline
\end{tabular}

From Table 1 above, the average total valid observations summed to $n=362$. An analysis of the descriptive statistics reveals that respondents attain agricultural output of between R50 000 and R60 000 annually (mean score $=3.22$ ). This level of performance is supported by land sizes averaging 16-20 hectares. Both short-term and long-term credit were in the range of R35 000 to R110 000. With labour hours per person per day dedicated to the farm on a day-to-day basis, it appears less convincing that the resources dedicated to the farm by the respondents are sufficient to maximise production particularly given land sizes of 11 to 20 hectares. All variables in the estimated model were found to be positively and significantly correlated (See Table 2 below).

Table 2: Correlation Matrix for Variables for the Agricultural Output Model

\begin{tabular}{|c|c|c|c|c|c|c|}
\hline & $\mathrm{AO}$ & Land & Labour & STC & LTC & Rain \\
\hline $\mathrm{AO}^{*}$ & 1 & .000 & .004 & .000 & .000 & .066 \\
\hline Land & & 1 & .000 & .000 & .000 & .116 \\
\hline Labour & & & 1 & .016 & .003 & .152 \\
\hline $\mathrm{STC}^{* *}$ & & & & 1 & .000 & .059 \\
\hline $\mathrm{LTC}^{* * *}$ & & & & & 1 & .308 \\
\hline Rainfall & & & & & & 1 \\
\hline
\end{tabular}

${ }^{*}$ Agricultural Output; ${ }^{* * *}$ Short-term credit; ${ }^{* * * *}$ Long-term credit

Several significant relationships are evident from Table 7 above. Agricultural output is observed to be strongly and positively correlated with land, labour, both short-term and long-term credit and rainfall ( $\mathrm{p}<.05)$. Land, labour and long-term capital portrayed positive relationships with rainfall albeit insignificant. The residuals were normally distributed as can be read from Figure 2 below. 


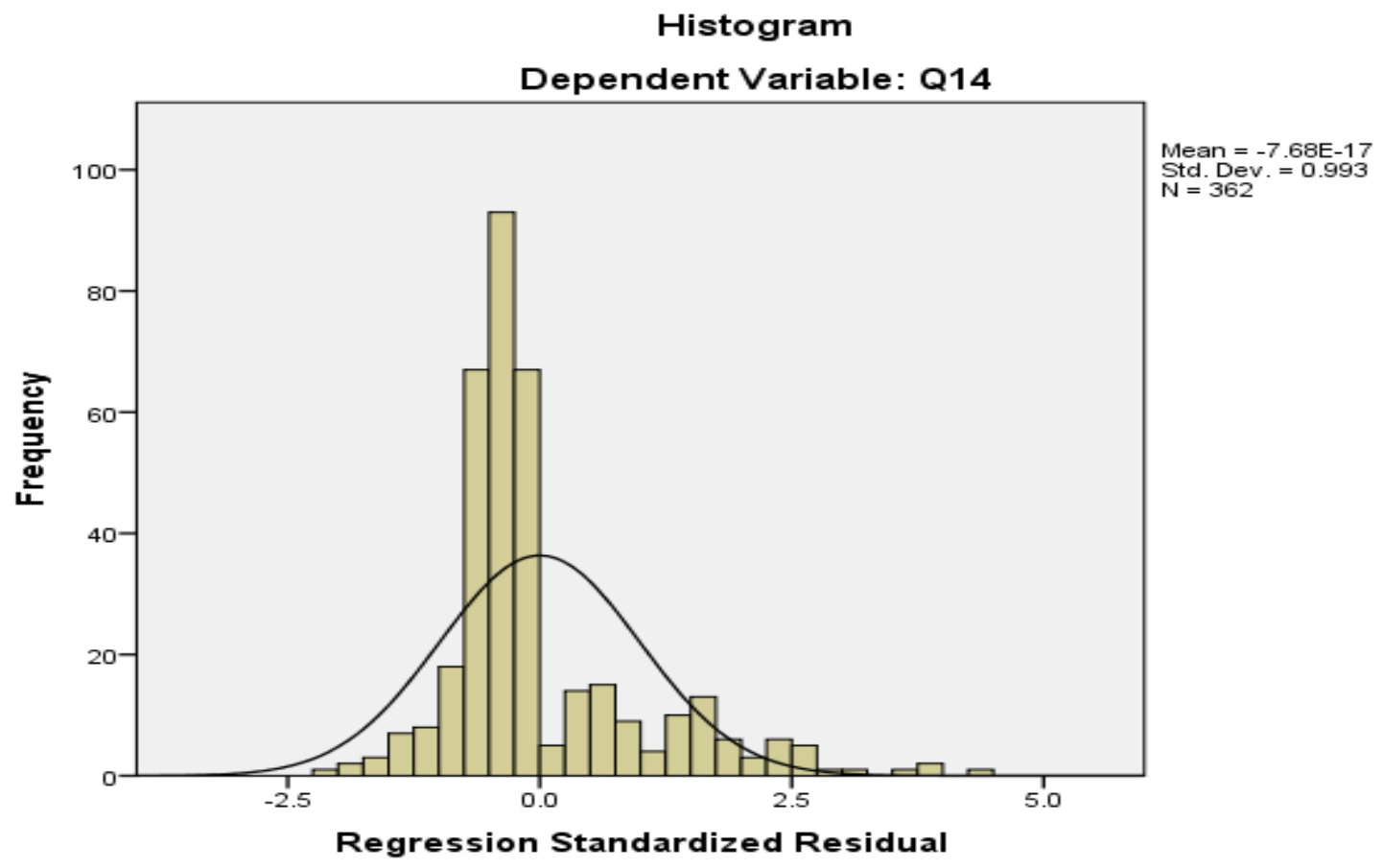

Figure 2: Normality Test: Agricultural Output Model

\subsection{Bivariate Correlation Analysis}

Table 3 below presents the chi-square test results for bivariate correlations between the endogenous variable and predictor variables in the hypothesis. All the predictor variables were observed to have significant correlations with agricultural output $(\mathrm{p}<0.05)$

Table 3: Pearson Chi-square Test between predictors and agric output

\begin{tabular}{ccccc}
\hline Item No. & Relationship & Value & df & Chi-sq \\
\hline 1 & Land size & 38.242 & 20 & $0.008^{* * * * *}$ \\
2 & Short-term debt & 70.931 & 25 & $0.000^{* * *}$ \\
3 & Long-term debt & 111.907 & 25 & $0.000^{* *}$ \\
\hline
\end{tabular}

$* ; * * ; * *$ denotes significance at $1 \%, 5 \%$ and $10 \%$ respectively.

\subsection{Results Of Regression Analysis And Discussion}

The estimated model for agricultural output portrayed a good fit. Table 4 shows the model summary in which both R-Squared and Adjusted R-Squared were significant. The Durbin Watson statistic of 1.828 satisfies the minimum criterion for goodness of fit $(1.4<\mathrm{DW}<2.4)$. The Analysis of Variance (ANOVA) confirmed the overall model significance at $95 \%$ as shown in Table $5(\mathrm{p}<0.05)$.

Table 4: Model Summary ${ }^{\mathrm{b}}$

\begin{tabular}{ccccc|ccccc}
\hline Model & \multirow{2}{*}{ R } & R Square & $\begin{array}{c}\text { Adjusted } \\
\text { R Square }\end{array}$ & $\begin{array}{c}\text { Std. Error Of } \\
\text { The Estimate }\end{array}$ & $\begin{array}{c}\text { R Square } \\
\text { Change }\end{array}$ & F Change & df1 & df2 $\begin{array}{c}\text { Sig. F } \\
\text { Change }\end{array}$ \\
\hline 1 & $.387^{\mathrm{a}}$ & .150 & .138 & .960 & .150 & 12.549 & 5 & 356 & .000 \\
\hline
\end{tabular}

a. Predictors: (Constant), Rainfall, Q22, Q10, Q7, Q21

b. Dependent Variable: Q14

Durbin-Watson 1.828 
Table 5: One Way Analysis of Variance (ANOVA ${ }^{\mathrm{a}}$ )

\begin{tabular}{llccccc}
\hline \multicolumn{1}{l}{ Model } & Sum of Squares & df & Mean Square & F & Sig. \\
\hline 1 & Regression & 57.789 & 5 & 11.558 & 12.549 & $.000^{\mathrm{b}}$ \\
& Residual & 327.882 & 356 & .921 & & \\
& Total & 385.671 & 361 & & & \\
\hline
\end{tabular}

a. Dependent Variable: Q14

b. Predictors: (Constant), Rainfall, Q22, Q10, Q7, Q21

The results of the multiple regression are shown in Table 6 below. The reported coefficients show the extent to which the regressors contribute to the model fit. Serve for land and rainfall, all the independent variables were observed to be significant at $95 \%$ confidence level $(\mathrm{p}<0.05)$. All the standardised beta coefficients were found to be positive implying that the independent variables contribute significantly to agricultural output. When ranked, both short-term and long-term credit are found to make the highest contribution (beta $=0.144$ for short term credit and 0.231 for long-term credit). Although insignificant, the beta coefficients for both land and labour are found to be positive implying that they are necessary for agricultural production. The coefficient of determination $\left(\right.$ both $\mathrm{R}^{2}=$ $15 \%$ and adjusted $\mathrm{R}^{2}=14.8 \%$ ) confirm that agricultural output is explained by the predictor variables. The coefficient of determination must fall between 0 and 1 . If close to zero, the predictor variable explains very little of the dependent variable while if close to 1, the predictor variables explain most of the variation in the dependent variable. These results are consistent with and Chisasa and Makina (2013) in an earlier study for South Africa using secondary data.

Table 6: Coefficients ${ }^{\mathrm{a}}$

\begin{tabular}{lccc}
\hline Model & Standardised Coefficients & t-statistic & Significance \\
\hline (Constant) & Beta & & .050 \\
Land & & 1.963 & $.028^{* *}$ \\
Labour & .119 & 2.207 & .387 \\
STD $^{1}$ & .045 & .865 & $.008^{* * *}$ \\
LTD $^{2}$ & .144 & 2.650 & $.000^{* * *}$ \\
Rainfall & .231 & 4.290 & .296 \\
\hline
\end{tabular}

a. Dependent Variable: Output

1=Short-term debt; $2=$ Long-term debt

$*, * *$, and $* * *$ denote significance level at $10 \%, 5 \%$ and $1 \%$.

\subsection{Discussion Of Results}

The results of this study have demonstrated that smallholder farmers need credit to improve their output. A $1 \%$ increase in short-term credit will result in a $0.14 \%$ increase in agricultural output holding other factors constant. Furthermore, a $1 \%$ increase in long-term credit will result in a $0.23 \%$ increase in output. These results suggest that smallholder farmers need more long-term credit facilities. The long term credit may be utilised to purchase capital equipment required to mechanise farming operations. These may be in the form of tractors, irrigation equipment and combine harvesters. On the other hand, short-term credit is required to purchase inputs such as improved seed varieties, fertiliser and pesticides, and to pay wages and salaries. Our results are in line with those of Kohansal et al. (2008) who investigated the effect of credit accessibility of farmers on agricultural investment. Using a Logit model, the authors observed a strong relationship between access to credit, increased profitability of the farmer and poverty reduction in the agricultural sector. Similarly, Gosa and Feher (2010) found trade credit to enhance the competitiveness and profitability of farmers in Romania. Al Rjoub and Al-Rabbie (2010) examined whether changes in the level of credit supply by banks in Jordan would affect output. As with other empirical studies discussed above and Adewale (2014), results showed a positive and statistically significant correlation between bank credit and output growth.

Land has also been observed to have a significant contribution to production and its positive coefficient suggests that a $1 \%$ increase in land size will result in a $0.12 \%$ increase in farm output. These results correlate with those of Feder et al. (1990) who concluded that the quantity of land is an important and statistically significant determinant of output supply for constrained and unconstrained households in Chinese agriculture. 
Both labour and rainfall were observed to be insignificant. However, their coefficients were positive suggesting that they are vital factors in the agricultural production function. Similar results were observed by Ehikioya and Mohammed (2013) in Nigeria.

\section{CONCLUSION}

This paper examined the role of bank credit in the performance of smallholder farmers in South Africa. A survey methodology was employed utilising survey data from the North West and Mpumalanga Provinces of South Africa. Multiple regression analysis was performed using the Ordinary Least Squares (OLS) technique to establish the relationship between the performance of smallholder farmers proxied by seasonal output and bank credit, land, labour and rainfall as exogenous variables.

Results show that the relationship between credit and agricultural output is positive and significant. An increase in credit supply to smallholder farmers will increase the level of output via purchases of inputs and pesticides using short-term credit and capital equipment such as tractors and farm equipment required for the production process. Furthermore, the study has revealed that there is a positive and significant relationship between land and agricultural output. Labour and rainfall were found to be insignificant albeit positive.

In conclusion, the lesson that emanates from this study is that continuous supply of credit to smallholder farmers has the capacity to stimulate agricultural output, expand farming operations, create employment and alleviate poverty. The study recommends the development of credit instruments that suits the risk profile of smallholder farmers.

\section{AUTHOR INFORMATION}

Joseph Chisasa is a Senior Lecturer at the University of South Africa. He holds a Master of Science Degree in Finance and a Bachelor of Commerce Degree in Banking (Honours). He is a Certified Associate of the Institute of Bankers of South Africa and an Associate Member of the Institute of Credit Management of South Africa. Prior to joining the University of South Africa, Joseph worked as a Corporate Banker at Barclays Bank of Zimbabwe Limited. He has published in international journals including the International Business and Economics Research Journal. His research interests are in banking and credit risk management. Email: Chisaj@unisa.ac.za

\section{ACKNOWLEDGEMENTS}

The paper is based on an ongoing doctoral research project by the author entitled: An Empirical Study of the Impact of Bank Credit on Agricultural Output in South Africa. Correspondence should be addressed to Joseph Chisasa at UNISA, Private Box 392, Pretoria 0003, e-mail: Chisaj@unisa.ac.za, Telephone: +27 (12) 4294613.

\section{REFERENCES}

1. Adewale, A.R. (2014). Financial regulation, credit consumption and economic growth: An analysis of the National Credit Act in South Africa. The Journal of Applied Business Research, 30(2) 367-378.

2. Al Rjoub, S.A.M. \& AL-Rabbaie, A. (2010). Does bank lending affect output? Evidence from an emerging market. International Research Journal of Finance and Economics, 46, 63-70.

3. Ammani, A.A. (2012). An investigation into the relationship between agricultural production and formal credit supply in Nigeria. International Journal of Agriculture and Forestry, 2(1) 46-52.

4. Barron, J., Enfors, E., Cambridge, H. \& Moustapha, A. M. (2010). Coping with rainfall variability: Dry spell mitigation and implication on landscape water balances in small-scale farming systems in semi-arid Niger. Water Resources Development, 26(4) 543-559.

5. Baumol, W.J. \& Blinder, A.S. (2006). Economics: Principles and Policy. $10^{\text {th }}$ Edition. Thompson SouthWestern, New York.

6. Bayemi, P.H., Webb, E.C., Ndambi, A., Ntam, F. \& Chinda, V. (2009). Impact of management interventions on smallholder dairy farms of the western highlands of Cameroon. Tropical Animal Health and Production, 41:907-912. 
7. Blignaut, J., Ueckermann, L. \& Aronson, J. (2009). Agriculture production's sensitivity to changes in climate change in South Africa. South African Journal of Science, 105, 61-67.

8. Bratka, V. \& Praulins, A. (2009). Efficiency of borrowed capital in Lativian agricultural holdings. Economics and Management, 14, 138-144.

9. Carter, M.R. (1989). The impact of credit on peasant productivity and differentiation in Nicaragua. Journal of Development Economics, 31, 13-36.

10. Chisasa, J. \& Makina, D. (2013). Bank credit and agricultural output in South Africa: A Cobb-Douglas empirical analysis. International Business and Economics Research Journal, 12(4) 387-398.

11. Chisasa, J. \& Makina, D. (2012). Trends in credit to smallholder farmers in South Africa. International Business and Economics Research Journal, 11(7) 771-784.

12. $\quad$ Cobb, C.W. \& Douglas, P.H. (1928). A Theory of production. The American Economic Review, 18(1) 139165 .

13. Coetzee, G., Meyser, F. and Adam, H. (2002) 'The financial position of South African Agriculture', Department of Agricultural Economics, Extension and Rural Development, University of Pretoria, Working Paper: 2002-01.

14. Deininger, K., Jin, S. \& Nagarajan, H.K. (2007). Land reforms, poverty reduction, and economic growth: Evidence from India. World Bank Policy Research Paper no. WPS4448.

15. Development Bank of Southern Africa. (2011) Annual Report. [Online] Available from http://www.dbsa.org [Accessed: 2014-03-03].

16. Dhehibi, B. \& Lachaal, L. (2006). Empirical evidence of productivity growth in Tunisian agriculture: 1961 - 2000. African Development Review, 18(2) 248-257.

17. Driscoll, J.C. 2004. Does bank lending affect output? Evidence from the U.S. states. Journal of monetary economics, 51: 451-471.

18. Ehikioya, I. \& Mohammed, I. (2013). Commercial bank credit accessibility and sectoral output performance in a deregulated financial market economy: empirical evidence from Nigeria. Journal of Finance and Bank Management, 1(2) 36-59.

19. Enoma, A. 2010. Agricultural credit and economic growth in Nigeria: An empirical analysis. Business and Economics Journal, no 14, 1-7.

20. Fanadzo, M., Chiduza, C. \& Mnkeni, P.N.S. (2010). Overview of smallholder irrigation schemes in South Africa: Relationship between farmer crop management practices and performance. African Journal of Agricultural Research, 5(25) 3514-3523.

21. Fatoki, O. \& Odeyemi, A. (2010). Which new small and medium size enterprises in South Africa have access to bank credit? International Journal of Business Management, 5(10) 128-136.

22. Gosa, V. \& Feher, A. (2010). Financial resource implications on agriculture results. Lucrari Stintifice Seria I, 12(3): 7-14.

23. Jaffe, M. \& Zeller, M. (2010). Land regulations and agricultural production: The case of Cuba's cattle sector. Post-Communist Economies, 22(4) 531-545.

24. Kohansal, M.R., Ghorbani \& Mansoori, H. (2008). Effect of credit accessibility of farmers on agricultural investment and investigation of policy options in Khorasan-Razavi Province. Journal of Applied Sciences, 8(23) 4455-4459.

25. Kumar, A., Singh, K.M. \& Sinha S. (2010). Institutional credit to agricultural sector in India: Status, performance and determinants. Agricultural Economics Research Review, 23, 223-264.

26. Lahiff, E. \& Cousins, B., (2005). Smallholder agriculture and land reform in South Africa. Institute of Development Studies Bulletin, 36(2) 127-131.

27. MacCleod, N.D., MacDonald, C.D. \& van Oudtshoorn, F.P. (2008). Challenges for emerging livestock farmers in Limpopo province, South Africa. African Journal of Range and Forage Science, 25(2) 71-77.

28. Obilor, S.I. (2013). The impact of commercial banks' credit to agriculture on agricultural development in Nigeria: An econometric analysis. International Journal of Business, Humanities and Technology, 3(1) 8594.

29. Oettle, N., Fakir, S., Wentzel, W., Giddings, S. and Whiteside, M. (1998) 'Encouraging sustainable smallholder agriculture in South Africa' Agricultural Services Reform in Southern Africa.

30. Palmer, K. \& Sender, J. (2006). Prospects of on-farm self-employment and poverty reduction: An analysis of the South African income and expenditure survey 2000. Journal of Contemporary African Studies, 24(3) 347-376. 
31. Rother, H., Hall, R. \& London, L. (2008). Pesticide use among emerging farmers in South Africa: Contributing factors and stakeholder perspectives. Development Southern Africa, 25(4) 399-424.

32. Rouault, J. \& Richard, Y. (2003). Intensity and spatial extension of drought in South Africa at different time scales. Water SA, 29(4) 489-500.

33. Sial, M.H., Awan, M.S. \& Waqas, M. (2011). Institutional credit and agricultural production nexus. MPRA Paper No. 30392. [Online] Available from http://mpra.ub.uni-muenchen.de/30932/

34. Sidhu, R.S.S, Vatta, K. \& Kaur, A. (2008). Dynamics of institutional agricultural credit and growth in Punjab: Contribution and demand-supply gap. Agricultural Economics Research Review, 21, 407-414.

35. Simsir, N.C. (2012). An econometric analysis of the relationships between economic growth and agricultural credits for pro-poor growth in Turkey. International Journal of Social Sciences and Humanity Studies, 4(2) 355-364.

36. Sogo-Temi, J.S. \& Olubiyo, S.O. (2004). The role of agricultural credit in the development of agricultural sector: The Nigerian case. African Review of Money, Finance and Banking, 101-116.

37. Udoh, E. (2011). An examination of public expenditure, private investment and agricultural sector growth in Nigeria: Bounds testing approach. International Journal of Business and Social Science, 2(13) [Special Issue]: 285-292.

38. Zuberi, A.H. 1989. Production function, institutional credit and agricultural development in Pakistan. The Pakistan Development Review, 28(1) 43-56. 
NOTES 